\title{
"Prosperidade" na Década de 1990: Etnografia do Compromisso de Trabalho entre Deus e o Fiel da Igreja Universal do Reino de Deus*
}

\author{
Diana Nogueira de Oliveira Lima
}

\section{INTRODUÇ̃̃o}

$\mathrm{O}$ cenário é conhecido. Crise de endividamento, descontrole inflacionário e diversas tentativas de estabilização monetária são os traços da fisionomia socioeconômica do "continente da esperança" na década de 1980. No mundo do trabalho, no Brasil, a acentuação dos processos de exclusão do mercado formal de ocupação, provocada pela crise do modelo fordista-taylorista de produção, vem acompanhada de uma depressão do sistema público e de uma decorrente deterioração dos mecanismos de proteção social contra o desemprego e a miséria, provocando um agravamento das já historicamente precárias condições de existência da pobreza urbana (Fernandes, 1978; Franco, 1997; Freyre, 2003; Souza, 2003).

Em um ambiente de $80 \%$ de inflação mensal e de longa estagnação econômica, portanto, é empossado no Brasil, em março de 1990, o primeiro presidente eleito pelo voto direto após 29 anos. Convencido de que as dificuldades que se impunham ao setor público e à sociedade brasilei-

\footnotetext{
* O projeto A Teologia da Prosperidade e o Valor do Dinheiro no Brasil Contemporâneo foi financiado pelo Conselho Nacional de Desenvolvimento Científico e Tecnológico CNPq com uma bolsa de Pós-Doutorado Júnior - PDJ. Durante a realização da pesquisa, estive vinculada ao Departamento de Antropologia Cultural do Instituto de Filosofia e Ciências Sociais - IFCS/Universidade Federal do Rio de Janeiro - UFRJ.
}

DADOS - Revista de Ciências Sociais, Rio de Janeiro, Vol. 51, nํ1, 2008, pp. 7 a 35. 
ra se deviam ao comportamento corrosivo dos burocratas e governantes que o antecederam, e endossando as recomendações aos países periféricos para retomada do crescimento econômico, desenvolvimento e alcance da igualdade social que tiveram "Consenso [em] Washington", Fernando Collor de Mello tratou de cumprir sua promessa eleitoral de "ruptura com a Tradição, por ele associada às raízes ibéricas do atraso burguês, o patrimonialismo e o cartorialismo, a que o remédio heróico do desmantelamento das estruturas do Estado e de uma política de fronteiras econômicas abertas deveria dar um fim" (Werneck Vianna, 2006:18-19, ênfase no original). Assim, pôs-se a diminuir a presença do Estado na arena econômica, tomou suas medidas para estabilização da moeda e implementou, no país, a "abertura comercial" e a "privatização" ser predominantemente presidida pelos princípios do "mercado livre", segundo os quais as prioridades devem ser a mobilização da capacidade empresarial, dos recursos produtivos e dos mecanismos de inovação e produção de novas tecnologias, o estímulo ao funcionamento desregulado dos mercados - o financeiro e o do trabalho - e o desimpedimento da comercialização interna e externa.

Aqui não estarão à prova as condições que permitiram a difusão dessa matriz no mundo desenvolvido nos anos 1980, ou como ela avançou pela América Latina na década de 1990. Tampouco avaliarei a propriedade de suas diretrizes, nem se elas estão efetivamente informando a totalidade das práticas econômicas. Para a condução desta análise importa apenas sublinhar que, a partir do começo da década de 1990, parâmetros nitidamente importados do imaginário neoliberal - tais como o Estado mínimo, o empreendedorismo, a autonomia individual, a eficiência, a competitividade e a produtividade - se instalam no debate político e intelectual, nas tomadas de decisão em grupos empresariais e financeiros, em alguns dos grandes partidos políticos, em certos meios acadêmicos, jornalísticos e também entre tecnocratas.

No interior das grandes organizações, algumas criadas pela "privatização", em benefício da "eficiência" foram adotados programas agressivos de corte de pessoal e, em muitos casos, definida uma nova política salarial. Em nome da "gestão participativa", os profissionais que so-

\footnotetext{
* Uso aspas quando, seguindo a prática em antropologia, incorporo ao texto vocábulos da língua portuguesa que, no ambiente empírico em análise, são empregados em um sentido particular. Tais vocábulos, exprimindo categorias, são transcritos e importados exatamente como circulam porque constituem dados de grande relevância para meus informantes.
} 
“Prosperidade" na Década de 1990: Etnografia do Compromisso de Trabalho...

breviveram a esses programas foram submetidos ao esquema de salário variável. Isso significa que, desde a segunda metade da década de 1990, a remuneração total passou a se dividir em duas partes: uma parcela fixa e outra variável, em função de resultados individuais, departamentais e da própria empresa como um todo. Trabalhar muito, "dar resultado" e, por isso, ser bonificado com participações nos lucros e premiado com, por exemplo, viagens, passou a ser a lógica imperante em muitos contextos organizacionais. Enquanto, para alguns profissionais, todo esse esquema é uma distorção que provoca infelicidade e que, permanentemente, os ameaça de desemprego, para outros trata-se de um grande estímulo a seu "espírito empreendedor". Não custa lembrar que este se manifestou ainda, embora com diferentes contornos, entre os profissionais que, atingidos pelos cortes de pessoal, optaram por ou dispuseram dos recursos financeiros necessários para tomar o caminho do "próprio negócio".

$\mathrm{Na}$ imprensa brasileira, o jornalismo econômico cresceu e ganhou prestígio durante o regime militar. Ao mesmo tempo em que reprimia a liberdade de expressão em assuntos políticos, o governo estimulava o noticiário econômico, no qual eram divulgadas as conquistas e os avanços que o legitimavam perante a sociedade. Assim, os jornais foram levados a substituir o noticiário político pelo econômico e por notícias internacionais, e as editorias de economia, que tinham antes um lugar secundário, ampliaram seu espaço, atendendo a um público de tomadores de decisão, tecnocratas e formadores de opinião (Abreu, 2003:13-74).

Com a redemocratização, os jornalistas da área continuaram a desfrutar de grande prestígio nas redações. Porém, o perfil atual da imprensa econômica é mais técnico e muito menos engajado do que durante o regime militar, quando os jornais tinham em seus quadros artistas, escritores, professores universitários e jornalistas, motivados à profissão por razões políticas e que, em muitos casos, apesar da censura, conseguiam fazer do jornal um instrumento de contestação. Em sua pesquisa, Abreu (ibidem) constata que muitos jornalistas engajados nas décadas de 1970 e 1980 têm agora uma atitude antimilitante em nome de uma atuação mais profissional. Segundo alguns jornalistas entrevistados por ela, ironicamente, hoje, quando o país vive um momento de plena liberdade de imprensa, há um desinteresse crescente por temas políticos. Os "leitores ou telespectadores têm interesse cada vez maior pelo noticiário jornalístico utilitário; o público se interessa por aquilo 
que pode usar, busca informações que possam lhe trazer algum ganho direto e imediato" (ibidem:68).

Os cadernos diários contam com a participação de economistas e têm agora em torno de seis páginas. Eles divulgam as notícias econômicas do dia, informações sobre empresas e instituições governamentais, notas, entrevistas, cotações de bolsas e de moedas estrangeiras, instruções sobre aplicações e colunas analíticas. Fazendo par com esses cadernos diários, há os jornais integralmente dedicados aos assuntos econômicos, como a Gazeta Mercantil e o Valor Econômico, as diversas publicações e periódicos que incorporam a linguagem do management e cobrem assuntos relativos às variáveis do mercado, e os manuais de "auto-ajuda", que prometem fornecer a uma legião de leitores aderentes à lógica mercantil os ensinamentos necessários ao "sucesso" (Boltanski e Chiapello, 1999).

Ao mesmo tempo em que cresce, na mídia e na palavra cotidiana, a fala sobre a economia - para, além de fornecer receitas sobre investimentos e diferenciação no mercado competitivo, denunciar a "crise econômica" que se agrava na década de 1980 e avança pelos anos 1990, e lamentar seus efeitos sobre a "classe média", contribuindo para o assentamento da representação de que o problema da (e a solução para a) sociedade brasileira é meramente econômico (Souza, 2003:93-188) -, pronuncia-se, paralelamente, o segmento da mídia impressa voltado para a exposição do mundo dos indivíduos que, apesar da crise continuada, conseguiram ter "sucesso". Novas colunas sociais, além das já existentes, são criadas nos informativos diários, e inúmeros semanários focados no retrato da vida dos bem-sucedidos são lançados nesse momento. Os tipos sociais monitorados por esse segmento, que as revistas $\mathrm{Ca}$ ras e Quem Acontece atualizam de modo emblemático, estão sempre contentes e vestem-se de maneira evidentemente dispendiosa. São de origem socioeconômica variada e cumpriram trajetórias profissionais muito diversas, sempre relatadas como corajosas eárduas, mais ou menos recentes. Eles aparecem invariavelmente em situações de festa, de glória e de lazer, que se desenrolam em residências ou arredores ricamente decorados. É assim, no desfrute de suas "conquistas", que a vitória é publicamente explicitada.

Na televisão, o processo em descrição desenrola-se na mesma direção. Basta lembrar a existência dos programas de entrevistas e de variedades que, de modo geral, dão voz a diferentes tipos de "vencedores"; os 
“Prosperidade" na Década de 1990: Etnografia do Compromisso de Trabalho...

tão falados reality shows que mostram, ao vivo, como, através da competição, nascem as ditas celebridades instantâneas; a exploração das tensões entre tradição e modernidade, hierarquia e individualismo nas telenovelas etc.; além da presença das notícias econômicas nos telejornais.

Desse modo, em tempos de "economia de mercado", é inequívoca, nos veículos de comunicação de massa, a autoridade atribuída aos esquemas de pensamento do mercado e a ênfase no elogio aos chamados "batalhadores". A idéia de que o "sucesso" - corolário de riqueza material e de celebridade - está ao alcance de todos os indivíduos que dispuserem de iniciativa, espírito empreendedor, coragem e perseverança para trabalhar competitivamente irrompe em todos os canais de comunicação, reiteradamente conotados com grande positividade.

Em outro momento, examinei o modo como alguns segmentos da "elite" do Rio de Janeiro vêm se servindo dos elementos do universo mercantil para criarem - em torno da noção de "sucesso" - um novo critério classificatório na sociedade brasileira (Lima, no prelo). Importava, naquele momento, verificar como esses segmentos consomem, material e simbolicamente, os objetos fabricados pelo capitalismo e como se inserem ativamente no mundo da produção capitalista. Nesse estudo, baseei-me em uma análise de material de imprensa sobre a rede de relações conhecida como Nova Sociedade Emergente - uma categoria social que ganhou notoriedade na mídia na década de 1990 e que perpetua, já há três gerações, o trinômio trabalho árduo, dinheiro e consumo conspícuo como valor positivo -, notadamente a emblemática revista Caras e as colunas sociais do jornal O Globo. Em 1994, pela primeira vez, a jornalista Hildegard Angel tomou de empréstimo da linguagem econômica a categoria "emergente" e usou essa fórmula, em suas colunas, para apresentar à "sociedade" e, insistentemente, por seis anos, destacar e elogiar o "sucesso" de uma seleção de indivíduos recémchegados à Barra da Tijuca e recém-enriquecidos através do trabalho empreendedor em negócios, originalmente pequenos, como padarias, marmorarias, açougues, nos subúrbios cariocas. Apoiei-me ainda na observação direta do estilo de vida dos integrantes dessa rede para perceber o funcionamento, na sociedade brasileira contemporânea, daquilo que chamei de ethos emergente e identifiquei ter-se tornado característico de alguns meios sociais recentemente, quando, durante o governo Collor, o Brasil adotou, em sua política econômica, os princípios do "mercado livre". 
Diana Nogueira de Oliveira Lima

Para dar continuidade à reflexão sobre a simbólica referente ao "sucesso" (a essa concepção de sucesso que corresponde a êxito material) no Brasil contemporâneo e pensar sobre os elementos obtidos durante a pesquisa antropológica em andamento na cidade do Rio de Janeiro desde setembro de 2005, a esse breve panorama de acontecimentos relativos ao universo da economia associarei outra ordem de dados - numéricos e etnográficos - atinentes à realidade social brasileira. O objetivo é, seguindo a pista da trajetória ocupacional de uma rede de fiéis da Igreja Universal do Reino de Deus - IURD, defensora da Teologia da Prosperidade, que se mostram entusiasmados com o que consideram o efeito da conversão em suas vidas, buscar compreensão antropológica sobre o modo como foi apropriado o sistema de termos e valores caro ao imaginário "neoliberal" entre indivíduos oriundos dos estratos urbanos mais pobres dessa sociedade. Em sua tese de doutorado, Wania Mesquita (2003) constata e detidamente analisa como os fiéis da IURD articulam a Teologia da Prosperidade e a opção pelo "negócio próprio". Considerando, como Duarte (2005:139-176), que é a visão de mundo mais abrangente dos atores sociais o que os orienta na opção por uma entre as tantas alternativas de adesão confessional disponíveis, a mim interessa ainda entender quem são, em termos de anseios, disposições e vivências, os sujeitos sociais de classes populares para os quais, na década de $1990^{1}$, essa articulação fornece as diretrizes para a realização de seu projeto de superação de suas condições originais de vida (Velho, 1987:13-37). Em especial, neste artigo, deixarei que falem três rapazes cujos percursos me parecem paradigmáticos do contexto social que venho etnografando desde fins de 2005. Eles são membros da "igreja do Largo do Machado" ${ }^{3}$ há cerca de dez anos e, como grande parte daquele público, embora não tenham nascido por ali, residem desde a infância nas imediações da igreja, entre o Bairro de Fátima e o Cosme Velho ${ }^{4}$. Além de serem muito desfavorecidos em termos de renda, esses indivíduos vivem - ou viviam, antes de se converterem -, há pelo menos duas gerações, uma situação de total não-integração no mercado de trabalho.

\section{IGREJA UNIVERSAL DO REINO DE DEUS, SEUS FIÉIS E SUA TEOLOGIA}

O Atlas da Filiação Religiosa e Indicadores Sociais no Brasil, produzido a partir dos microdados obtidos no Censo Demográfico de $2000^{5}$, revela que, no Censo de 1980, 3,9 milhões de pessoas declararam pertencer a uma das religiões pentecostais. Em 1991, esse número aumentou para 8,8 milhões de pessoas e, em 2000, chegou a 18 milhões. Segundo essa 
“Prosperidade" na Década de 1990: Etnografia do Compromisso de Trabalho...

mesma fonte, do ponto de vista demográfico, os pentecostais concentram-se nas zonas urbanas, congregam mais mulheres do que homens, mais adolescentes e crianças do que adultos, e mais negros, pardos e indígenas do que brancos. Em matéria de educação, têm um nível muito elementar, sendo que, muitos deles, foram alfabetizados em idade adulta. Quanto à situação econômica, é freqüente a presença de empregados domésticos com ou sem registro de trabalho e com baixo nível de remuneração ${ }^{6}$. Dentro desse quadro, a IURD - principal porta-voz da "teologia da prosperidade" - é a igreja que mais se expandiu desde sua criação no bairro da Abolição, no Rio de Janeiro, em 1977. Em 1991, tinha 269.000 fiéis; em 2000, esse número cresceu para 2,1 milhões de pessoas, o que representa $12 \%$ dos pentecostais ${ }^{7}$. Na década de 1990 , portanto, a Universal amplia seu número de membros em $25 \%$ a cada ano. As cidades do Rio de Janeiro e de São Paulo concentram a maior parte dessa população.

Na mensagem da IURD, a "abundância" é um valor central. Em seu sistema cosmológico, sagrado e desfrute terreno da fortuna não são antinômicos, como na visão de mundo das religiões de salvação (Weber, 1982:347-370; Sahlins, 1996), ao contrário, estão articulados. A Teologia da Prosperidade prega que, por meio da força performativa das palavras, o bom fiel poderá expulsar o Demônio, responsável pelos obstáculos que se impõem à sua vida, e terá acesso a tudo de bom que a existência terrena pode oferecer (saúde perfeita, harmonia conjugal, riqueza material, poder para subjugar o Demônio etc. $)^{8}$. Sua releitura da Bíblia liberta os conversos das exigências ascéticas prescritas pelo protestantismo histórico e pelas denominações pentecostais tradicionais, e os estimula a uma vida de "plenitude" aqui e agora. Segundo a doutrina da Igreja Universal, a relação entre o cristão e Deus se mantém nos termos da reciprocidade: para receber a graça do Senhor, ele deve "viver de acordo com a fé", entregar regularmente o dízimo e fazer suas ofertas, e "tomar uma atitude".

Desde o final da década de 1980, quando começa a ganhar visibilidade, a Universal mantém uma relação tensa com diferentes interlocutores, tais como a mídia, o Estado, a Igreja Católica e alguns segmentos acadêmicos. Gomes (2004:18-20) faz ver que o acirramento dos ânimos em torno da IURD é função de três questões que, apartadas da totalidade dos elementos que as constituem, costumam ser a ela associados pelas análises preocupadas em singularizá-la dentro do horizonte pentecostal: participação política, demônio e dinheiro. Na década de 1990, a 
IURD mobiliza uma crítica negativa ostensiva à maneira como articula "a cura, o exorcismo, a prosperidade". De modo geral, as acusações recaem sobre o modo como ela se serve de uma linguagem proveniente do mercado e da força persuasiva da mídia eletrônica para, lançando mão de uma mensagem teológica vazia, recrutar uma massa de fiéis que, como apontou Freston (1993:111), chega a ser, por vezes, pensada como ingênua e ignorante. Essas pessoas procurariam a Igreja Universal motivadas por seus anseios de ascensão social (Oro, 1993), e isso dever-se-ia ao fato de que, na IURD, a "fantasia dos fiéis de se tornarem 'milagrosamente' ricos é exacerbada" (Oro et alii, 2003:32).

Entre os analistas - tanto religiosos quanto científicos - que, a partir da década de 1990, centraram seu enfoque na oferta religiosa com o objetivo de desvendar o significado e as razões da expansão do pentecostalismo - e, em particular, do que se convencionou chamar de pentecostalismo da terceira onda ou neopentecostalismo - no Brasil, olhando para a história da instauração das igrejas no país, elementos constitutivos da religiosidade pentecostal, modos de expansão e tipos de atuação política das igrejas, são numerosos os que se mostram reticentes em relação à Igreja Universal do Reino de Deus (Bittencourt, 1994; Campos, 1997; Carneiro Campos, 1994; Hortal, 1991, 1994; Mariano, 1996; Siepierski, 1997). Mariz (1995) mapeia os argumentos que, na literatura mais recente, se somam ao da "mercantilização da fé" para, repetidamente, motivarem perspectivas depreciativas do neopentecostalismo. Características como imediatismo, pragmatismo, magia, charlatanismo, superficialidade teológica e, acima de todas, a de ser uma agência de exploração financeira dos pobres são atribuídas, em especial, à IURD. Em sua abrangente revisão dos estudos voltados para a categorização e o exame do universo protestante/pentecostal, cujo crescimento se manifesta tanto em número de adeptos quanto em termos de diversificação institucional, Giumbelli (2001) igualmente deixa claro o repúdio que a IURD suscita nos autores, entre outras razões, em função do que consideram o emprego de lógica mercantil por parte desse pentecostalismo de cura divina que fetichiza o dinheiro (Oro, 1993).

Embora, desde a década de 1990, a Igreja Universal tenha motivado um grande esforço analítico por parte de cientistas sociais que enriqueceram a discussão sobre as mudanças ocorridas na paisagem religiosa brasileira (Mariz e Machado, 1998; Birman e Leite, 2000), pouca ênfase tem sido devotada à compreensão de como os membros da Igreja Uni- 
“Prosperidade" na Década de 1990: Etnografia do Compromisso de Trabalho...

versal do Reino de Deus, defensora da Teologia da Prosperidade, explicam sua conversão e dão significado a seu compromisso confessional.

Quem são os sujeitos sociais de camadas populares urbanas que, na década de 1990, procuraram soluções para suas dificuldades justamente nessa teologia que estimula o trabalho empreendedor autônomo e promete a prosperidade no mundo àquele que "tomar uma atitude"? Como explicar que, apesar da amplitude das denúncias contra o suposto caráter mercenário e perverso da Igreja Universal, na década de 1990 se multiplicou o número de pessoas que aderem à sua comunidade moral e testemunham favoravelmente sobre as mudanças ocorridas em suas vidas ${ }^{9}$ ?

\section{AS "REUNIÕES DA FELICIDADE"}

Na Igreja Universal do Reino de Deus, os cultos são voltados, cada dia da semana, a um tema diferente, "mas tá tudo ligado um no outro", segundo esclarecimento fornecido por um informante. Segunda-feira é o dia da "Reunião dos Empresários"10; na terça-feira, os membros se reúnem para a "Sessão de Descarrego"; na quarta, o culto é dedicado aos "Filhos de Deus"; quinta-feira é a consagração da "Família"; sexta é dia do culto da "Libertação"; sábado é reservado para a "Terapia do Amor"; e, no domingo, fazem "Louvor e Adoração".

No segundo semestre de 2005, ainda sem ter feito contato com nenhum membro da IURD, durante algum tempo freqüentei os cultos na Catedral Mundial da Fé, para ganhar familiaridade com esse universo. Nesse período, em função de meus interesses de pesquisa, prestei particular atenção à "Reunião dos Empresários", que ocorre não apenas ali na Catedral mas em todos os templos da IURD. Não foi preciso um esforço especial para perceber, nessas reuniões, a tão alardeada referência aberta ao dinheiro, ao direito à prosperidade e à abundância, muito em acordo com a proposta descrita no site da IURD, permanentemente em sua página inicial:

As reuniões realizadas às segundas-feiras na Igreja Universal do Reino de Deus são para pessoas que sejam empresárias, que estejam passando por problemas financeiros e não aceitam mais viver nesta situação, bem como para quem busca crescimento financeiro.

Durante as reuniões, as pessoas desenvolvem potenciais, descobrem seus talentos, traçam objetivos e planejam cada detalhe para a realização de suas metas. 
De fato, ao longo das duas horas de duração do culto à "prosperidade", a prédica é explicitamente dirigida ao tema do dinheiro. Nessas ocasiões, não se fala apenas do dinheiro a ser doado à Igreja Universal pelos fiéis, mas também do dinheiro que se pode conquistar através da fé, como aconteceu com aqueles que sobem ao altar para dar seu "testemunho". Para tratar desse assunto, são empregados termos e conteúdos extraídos do campo semântico da economia, tais como "empresa", "negócio", "lucro", "contrato", "aumento da produção", "máquinas", "diferencial do produto no mercado", "desemprego", além da menção a grandes quantias ${ }^{11}$ que "você vai ganhar", "que você vai poder dar de dízimo quando Deus te abençoar". Nessas reuniões, além do dízimo, obrigatório, muitas vezes os crentes são enfaticamente estimulados a se aproximarem do altar e contribuírem para a "Obra de Deus" também pela doação de "ofertas". Porque - como é assim explicado - ao ajudarem a Igreja Universal do Reino de Deus na divulgação da "mensagem viva e poderosa do Evangelho do Senhor Jesus Cristo" e na eliminação do "Mal", os fiéis firmam um "compromisso com Deus" e têm, portanto, o direito de se sentirem "sócios de Deus".

A fórmula pastoral de Edir Macedo, fundador da IURD em 1977, é repetidamente enfatizada e fundamenta a recomendação de que os presentes, tendo provado sua fidelidade a Deus, exijam "dEle" uma prova de sua grandeza e "determinem" seu desejo de prosperar não como quem pede ou suplica mas como quem reivindica um direito.

As bases de nossa sociedade com Deus são as seguintes: o que nos pertence (nossa vida, nossa força, nosso dinheiro) passa a pertencer a Deus; o que é dEle (as bênçãos, a paz, a felicidade, a alegria e tudo de bom) passa a nos pertencer. Passamos a ser participantes de tudo o que é de Deus (Macedo, 2005:68).

Minha conversa com Vinícius ${ }^{12}$, vendedor de seguros e um dos prepos$\operatorname{tos}^{13}$ de Wilson - de quem falarei adiante - ajuda a compreender como os fiéis vivenciam o compromisso com Deus:

(D) A Lucimar me disse que você já foi pastor da Igreja...

(V) Já.

(D) Tão novinho? Com que idade você foi pastor?

(V) Dezenove pra vinte anos.

(D) E por que você deixou?

(V) Também não sei, até hoje.

(D) Você foi deixando aos poucos ou foi de um dia pro outro? 
“Prosperidade" na Década de 1990: Etnografia do Compromisso de Trabalho...

(V) Não. Deixando aos poucos... Foi aos pouquinhos.

(D) Mas você nem vai mais à Igreja?

(V) Vou.

A reticência dos correligionários dessa organização tão vastamente estigmatizada é uma característica conhecida entre os pesquisadores. Ganhei a confiança de Vinícius e pude transformar em material para investigação nosso encontro no escritório de Wilson, quando me apresentei como professora da universidade e esclareci que estava interessada em ouvir, dos fiéis, sobre a IURD.

(D) Como você entrou pra Igreja? Você pode me contar um pouco sobre a tua experiência de fé?

(V) Quando eu entrei na Igreja, eu tinha irmão. Éramos três, né? Três irmãos, a gente era o mais conhecido do... A senhora conhece o bairro do Rocha? Agente virou aquele bairro de cabeça pra baixo. Com 13 anos eu era um dos maiores ladrão de carro que tem no Rocha. Com 13 anos, e ele com 16 pra 17. Roubava de tudo. Aí, depois, eu conheci um obreiro, o obreiro conversou comigo, eu entrei na Igreja.

(D) Aí largou...?

(V) O roubo, a boca-de-fumo.

(D) Você freqüentava uma boca-de-fumo?

(V) Não, eu trabalhava numa boca-de-fumo.

Vinícius e seu irmão foram evangelizados no "meio da rua", afastaram-se de suas atividades e foram "viver direitinho", freqüentando a Igreja por três anos. Depois desse período, seu irmão saiu da IURD e voltou para o morro da Mangueira. Vinícius me pergunta se conheço o morro da Mangueira e me explica:

(V) Então? Ele era o responsável pelo morro da Mangueira. Ele tomava conta de uma parte do morro e morreu em guerra de facção. Esse é o meu irmão de sangue. Meu irmão de criação tá preso até hoje.

(D) E você ficou na Igreja?

(V) Permaneci, virei pastor, aí saí fora de pastor. Fiquei dois anos e pouco como pastor e saí fora.

(D) E você não sabe o porquê?

(V) Porque dei mole, pô ${ }^{14}$. Era pra eu não ter saído.

(D) E não dá pra voltar?

(V) Não.

(D) Não? A Igreja não te recebe? 
Diana Nogueira de Oliveira Lima

(V) Não, eu é que não quero. Eu já voltei, aí saí de novo, já voltei a fazer besteira. Agora parei. E agora eu tô nessa.

(D) Tá trabalhando? Você conheceu o Wilson na Igreja?

(V) Conheci. Eu já trabalhei pro Wilson, aí saí, aí voltei em dezembro.

(D) E você estudou?

(V) Até o segundo ano do segundo grau. Estudava pr'eles não poder me levar preso porque eu estudava. O Siro Darlan... tem no Código Penal que não pode levar preso menor que estuda. Ele tem que rodar três vezes pra ser preso. Mas eu sempre passava de ano. Nunca prestei atenção em aula nenhuma. Era o dia inteiro na sala dormindo, mas sempre passava de ano.

(D) Você é muito inteligente, então. A sua noiva é da Igreja?

(V) Vai mais do que eu.

(D) Você vai aos domingos?

(V) Quando dá, eu vou, que eu tô morando agora num lugar difícil. É perigoso pra mim. Muito perigoso.

(D) E você vai durante a semana?

(V) Eu vou na de quarta-feira, direto.

(D) E já foi na 'Reunião da Prosperidade'?

(V) Eu já fui, já fiz corrente... Mas primeiro eu tenho que crescer espiritualmente de novo. Porque se você não se limpa espiritualmente, não se afasta do Mal, como é que tu vai pedir alguma coisa pra Deus?

O raciocínio de Vinícius segue a lógica interna ao discurso institucional. Na IURD, ele aprendeu que Deus não deseja a pobreza para seus seguidores. "Esse negócio de ser pobre, de ser miserável, pra depois que morrer encontrar o paraíso, isso é invenção dos católicos. Isso não tá na Bíblia, não senhor", disse-me Wilson certa vez. Uma "vida abençoada", em harmonia com Deus, é uma "vida em abundância". Contudo, para conseguir alcançar essa vida, é preciso estar "limpo" e, como recomenda o pastor, "ter coragem para pular nos braços de Deus".

\section{ETNOGRAFIA DA "MUDANÇA DE VIDA"}

A história confessional de Wilson, membro da "igreja do Largo do Machado", na Zona Sul do Rio de Janeiro, começou na infância, quando, desde muito novo, era levado à Igreja Metodista pela família. Nessa época, todavia, "não sentia a fé". Por isso, explica Wilson, aos 11 anos de idade, "fora de igreja", ele "andava com amizades" e acabou sendo preso por roubo. Não roubava porque "faltava o de comer. Roubava porque queria tênis de marca e não tinha pra comprar". Apesar do des- 
“Prosperidade" na Década de 1990: Etnografia do Compromisso de Trabalho...

gosto que seu comportamento causava à mãe, até os 17 anos ele ficou "fora de igreja". Foi apenas em 1989 que, movido pela curiosidade, foi "ver o que era aquela doideira toda que tavam falando na mídia, aquele dinheirão que dá":

(W) Veio morar lá no apartamento, que minha mãe, constantemente, alugava um quarto, vaga, né? Porque o aluguel era caro e a gente tinha dificuldade pra pagar. Nisso, veio morar um rapaz com a gente, né? Ele era um ex-obreiro da Igreja Universal. Ele tinha sido obreiro, tinha saído e não tava na Igreja... Então, essa proximidade do nosso apartamento com a Igreja, acabou fazendo que o rapaz começasse a freqüentar de novo os cultos da Igreja e o camarada acabou voltando pra fé, vamos dizer assim. [...] Ele era... é ... agente do Ministério do Trabalho. Quer dizer, ganhava um bom salário, né, e tal. Só que ele vivia mal. Vivia na mão de agiota. Então o cara recebia o salário dele que, pô, ele era um agente do Ministério do Trabalho, concursado, não ganhava tão mal. Mas o cara não tinha nada. Sempre assim... Só que muito gente boa. Quando voltou pra Igreja e tal, aí a gente viu uma melhora na vida dele. Começou a melhorar, conseguiu pagar as dívidas dele todas. Ele era obrigado a expor pra gente porque devia pra gente. Eu gostava muito dele. Eu era novo, ele era um pouco mais velho e, não sei se dá pra dizer assim, mas ele foi o responsável, né?

Wilson sublinha que a adesão à IURD foi uma escolha ancorada em uma avaliação racional da teologia ali professada. Tomada a decisão pela adesão, Wilson foi "entrando em contato com Deus", se "dedicando espiritualmente na Igreja", até ser "levantado a obreiro", há oito anos. Ele se "afastou de amizades" para estar na Igreja Universal e "lutar para melhorar". "Eu escolhi ir pra Igreja porque quis. Quem quiser que vá comigo. Quem fala de alienação, não sabe o que tá falando. É só tu prestar atenção pra ver que o negócio ali é todo baseado na Bíblia. Quem não quiser é melhor sair pra lá. Eu optei".

Segundo ele, sua vida particular foi se desenvolvendo paralelamente ao desenvolvimento espiritual. No segundo ano de IURD, voltou aos estudos e concluiu o segundo grau. Um pouco mais tarde, "Deus colocou [em seu] caminho" a mulher com quem está casado e com quem, um pouco antes do planejado, teve dois filhos. No entanto, é sobre o domínio da profissão e das finanças que Wilson gosta de se estender ao falar das mudanças provocadas em sua vida pela entrada na fé. 
A literatura sobre pentecostalismo já atribuiu ao "apartamento do mundo" (Mintz, 1964; Novaes, 1985) a melhora observada em suas vidas por parte dos convertidos ${ }^{15}$. Além disso, está claro que ingressar em uma comunidade de fé significa passar a integrar uma rede social formada por pessoas com as quais se conta nos momentos de dificuldade e no interior da qual circulam informações e oportunidades. Finalmente, nas clássicas palavras de Weber, a "admissão à congregação é considerada como uma garantia absoluta de qualidades morais, especialmente as qualidades exigidas em questões de comércio" (1982:350). No percurso de Wilson, há mais elementos em jogo.

No bairro do Largo do Machado, existem atualmente dois templos da Igreja Universal do Reino de Deus. Além da pequena igreja que atraiu Wilson na juventude, há dois anos funciona outra, no espaço onde, antes, era um cinema. Desde a inauguração, meu informante e seus amigos adotaram esse segundo templo ${ }^{16}$. Portanto, é em um ambiente muito característico da IURD que tenho assistido aos cultos e encontrado pessoas que, confirmando os números apontados no estudo organizado por Fernandes (1998), assiduamente, toda semana - em média, três vezes -, ali se reúnem. Ultimamente, Wilson e sua família comparecem somente aos cultos dedicados ao "fortalecimento da fé", ao "louvor" e ao "crescimento espiritual", na quarta-feira à noite e no domingo de manhã. No entanto, pelo prazer de me mostrar o sentido da Igreja Universal em sua totalidade, porque, como ouvi em mais de uma ocasião, "as reuniões são todas ligadas", já estivemos várias vezes, juntos, em todas elas.

No Largo do Machado, as "Reuniões da Prosperidade" têm o mesmo objetivo geral que na Sede Mundial. Não obstante, como não poderia deixar de ser, tendo em vista se tratar de cultos conduzidos por um pastor que prega para sua "igreja", a prédica ali é mais acolhedora e remete mais diretamente às questões que desafiam o cotidiano dos presentes. No começo da sessão, todos se concentram em "clamar" a Deus que afaste o "Mal" e desça para "prover a mudança na vida" de todo aquele que, "acreditando na palavra, tem lutado todos os dias". As pessoas, então, oferecem-se como canal para que "Deus prove sua grandeza aos incrédulos e realize a vitória tão desejada". Em seguida, o tom de pedido é substituído pelo da confissão positiva ${ }^{17}$. "Aquele que crê pode determinar o que vai acontecer, porque vai acontecer, porque o Senhor vai tomar as providências para que o resultado apareça. Que assim seja". "Pela fé e pela certeza", todos agradecem com aplausos a Deus e, 
“Prosperidade" na Década de 1990: Etnografia do Compromisso de Trabalho...

obedecendo às instruções do pastor, dirigem-se ao altar para colocarem o dízimo no alforje e serem ungidos.

Às segundas-feiras, a prolongada explicação sobre a importância do pagamento do dízimo é toda formulada no código das relações econômicas. Nesse dia, ali no Largo do Machado, a preocupação com o financiamento da "Obra" cede quase que totalmente lugar à orientação de que Deus seja pensado como um sócio. "O que significa que você vai ter como sócio o dono do universo". Embora seja "o sócio que mais atua, porque é dono de tudo, você ainda sai com a maior parte dos lucros".

Normalmente, o pastor dedica uma parte do culto ao que Wilson chama de palestra. Para apoiar sua fala em exemplos de figuras conhecidas que "venceram na vida" a despeito dos muitos obstáculos, a cada semana distribui um pequeno texto que, em linguagem muito simples e didática, conta uma dessas histórias marcadas por grandes adversidades. Essas pessoas, na explicação do pastor, tiveram êxito porque encontraram dentro delas força para acreditarem em si mesmas.

Não me refiro apenas aos folhetos que divulgam os tão conhecidos "testemunhos", mas ao material utilizado para a transmissão didática da mensagem individualista do poder realizador da crença em si mesmo. "Vencendo com Estratégia", que reproduzo no conteúdo e na forma, em seguida, foi entregue à platéia durante uma das "Reuniões dos Empresários" e lido pausadamente pelo pastor:

Não à toa o boxe é chamado de 'a nobre arte'. Poucas lutas se vencem tanto com a cabeça como o boxe. E a luta do Zaire foi o exemplo clássico. Muhammad Ali, um mito que começava a entrar em decadência, ia desafiar o campeão mundial George Foreman, um fenômeno da força e agilidade que tinha se tornado campeão derrotando outro fenômeno, o campeão olímpico Joe Frazer. Naquela noite, africana, ninguém, a não ser os espectadores, acreditavam na vitória de Ali. $\mathrm{O}$ filme conta que os vestiários de Ali, antes da luta, pareciam mais uma sala de velório. Somente ele, saltitando feito um insano, contra tudo e contra todos, acreditava na própria vitória. Quando a luta começou, Ali partiu para cima de Foreman, com golpes desmoralizantes, mas notou em poucos minutos, já no primeiro assalto, que estava diante de alguém que era muito melhor que ele mesmo. O técnico de Ali conta que, ao soar o gongo, ele viu, pela primeira vez, o medo nos olhos de Muhammad Ali. E o técnico tentou fazê-lo desistir. Ele não tinha chance alguma. 
Diana Nogueira de Oliveira Lima

Mas Ali voltou ao ringue com outra tática. Durante sete assaltos, colocou-se nas cordas e deixou Foreman castigá-lo impiedosamente. Foreman golpeava com tudo o que tinha, em todos os espaços que podia. Ali foi duramente castigado no rosto, na linha da cintura, nos braços, mas esperou pacientemente a hora certa. E ela veio no oitavo assalto, quando Foreman já estava exausto de bater em Ali. Muhammad Ali, então, derrubou Foreman, nocauteando sem dó um dos maiores lutadores da história, levando a torcida ao completo delírio. Poucos minutos depois de acabada a luta, uma verdadeira tempestade caiu sobre o ringue, que tinha sido montado em um estádio de futebol. Foreman só se recuperou da depressão daquela derrota dois anos depois. E Muhammad Ali, mesmo tendo retomado o cinturão dos pesados, deixaria o boxe pouco tempo depois. Mas, naquele dia, o melhor de todos os tempos fez chover.

Ao cabo da explicação sobre como é possível perceber a força que está dentro de cada um e, com a bênção de Deus, usá-la contra o mal que os ronda, os fiéis cobram de Deus uma transformação dentro deles e "coragem para persistir e lutar sem desistir". Querem "lutar com estratégia". Querem o despertar de "um espírito vencedor que seja capaz de adotar uma tática para vencer no negócio e fazer a diferença". Nas palavras de Wilson:

Eu te falo, cara, esse tipo de reunião me ajudou demais na minha vida. Porque a reunião ali, acaba sendo uma... porque ali, na verdade, é o seguinte, é uma palestra também, né?... Me fez ver um monte de coisa que eu não conseguia entender, enxergar e acreditar também... Ele tenta te ensinar a batalhar por uma vida melhor, mas com Deus, né?... Existem várias maneiras de você se dar bem na vida. Não é só com Deus. Tem gente que, se bobear, detesta Deus e o cara é super bem financeiramente. E aí, tu vai falar o que desses casos? Á lá, aquele cara é ateu excomungado mesmo, mas o cara é bem de vida demais. Qual é a explicação, então? A explicação é que Deus, ele é justo, e solta pra todo mundo. Que que adianta eu ficar socado na igreja e quando chegar aqui fora não tomar nenhuma atitude?... Tem lance que depende de Deus demais, pra quem acredita também, né? Porque, pô, pra mim, cara, eu... eu... eu não conheci meu pai. Não conheci meu pai. Minha mãe, coitada, uma pensionista do INSS, entendeu? Não tinha, não tinha quem, na minha família não tinha muitos exemplos... Porque eu penso assim: às vezes, quando você tem o exemplo, tem teu pai, pô e tal, eu acho que fica mais fácil. Então eu busquei em Deus e encontrei na Igreja. Eu me lembro quando 
“Prosperidade" na Década de 1990: Etnografia do Compromisso de Trabalho...

eu larguei meu emprego. Ó só, que engraçado. Era em 93. Na época, eu ganhava três salário mínimo e eu trabalhava numa portaria de um prédio comercial na cidade. Aí eu tinha Unimed, tique refeição, né, tal. Aí, quem olhava assim pensava: pô, o cara tem plano de saúde, cesta básica, um monte de coisa, os direitos que eles agregam. Aí eu larguei aquilo pra ser camelô. Caramba! Nego ficou maluco comigo. Minha mãe falou comigo: 'Pô, Wilson, tu é maluco, como é que tu vai fazer isso? Se ainda fosse um Banco do Brasil, fez concurso e passou, Petrobras'. Que ela só pensa nisso. Povo do Norte a vida é essa. Só existe Petrobras e Banco do Brasil. Se tu não tá viciado na Petrobras ou no Banco do Brasil tu não é ninguém. Mas é (risos). O povo do Norte é assim. Pode ver que é. Agora nem tanto, mas antigamente, pô! Aí, meu irmão: 'Isso aí é a Igreja, é a Igreja, que tem que ser empresário. Tu quer ser empresário desse jeito, abrindo uma barraquinha de camelô? Eu falei: 'Mas tudo tem que ter um começo'. E peitei sair.

\section{O COMPROMISSO DE TRABALHO ENTRE DEUS E VINÍCIUS, WILSON, JEFFERSON}

Os valores estimulados pelo sistema moral da Igreja Universal do Reino de - "vitória", "mudança de vida", "prosperidade" - e repetidos em sua pedagogia voltada para o trabalho empreendedor autônomo "batalhar", "empresário", "colocar um diferencial no seu produto", em oposição não somente ao desemprego mas também ao emprego, ali unanimemente avaliado como algo que "já chega", pois é fonte de "vidinha, de miséria, de humilhação" e de "viver apertado em transporte" - não são outros que não os valores caros à ética profissional postulada pelo mercado livre e pós-social que se aloja no país nos anos 1990 do século XX. Os dados demográficos encontram na base da pirâmide social brasileira a grande maioria dos fiéis da Igreja Universal. Esses sujeitos sociais, evidentemente, não têm acesso a escolas de economia ou de business, não estão inseridos nas grandes empresas ou nos partidos políticos ou, se estão, não ocupam posições passíveis de participação nos lucros, não têm investimentos nem tomam decisões estratégicas ou similares. Não obstante, são atingidos pelos meios de comunicação e, portanto, ainda assim, estão inseridos no circuito social de difusão e discussão dos elementos mais abrangentes do ethos econômico que revitaliza o doux commerce e associa linear e positivamente "trabalho árduo" e "sucesso", insistentemente sublinhado pela palavra contemporânea hegemônica. 
Alguns autores defendem que a atratividade da IURD aos olhos dos pobres urbanos brasileiros, largamente expostos ao desemprego ou ao subemprego, reside na promessa de prosperidade que promove através de uma vigorosa estratégia proselitista ${ }^{18}$. Essa hipótese não esgota, contudo, a questão de por que essa denominação pentecostal que professa a Teologia da Prosperidade desde sua fundação em 1977 se torna atraente a ponto de ampliar seu número de fiéis em $25 \%$ a cada ano justo na década de 1990. No contexto social que examino, a pobreza sempre foi um forte desafio. Não obstante, até a década de 1990, os números sobre a penetração da Igreja Universal dão prova de que o conceito de compensação neste mundo (central na Teologia da Prosperidade) não havia alcançado a mesma legitimidade religiosa e, portanto, o mesmo apelo entre os pobres que ela passa a ter no período em que a exibição da glória dos "vencedores" vem ocupar tanto espaço, e de modo tão insistente, nos meios de comunicação seculares. Até a década de 1990, confirmando o que diz Geertz sobre o sofrimento como problema religioso, as religiões cristãs - cada uma a seu modo, a Igreja Católica, bem como as igrejas pentecostais tradicionais, sendo a Assembléia de Deus a mais expressiva, presente no país em 1910 - ofereciam aos pobres orientação sobre "como sofrer, como fazer da dor física, da perda pessoal, da derrota frente ao mundo ou da impotente contemplação da agonia alheia algo tolerável, suportável - sofrível, se assim podemos dizer" (1989:76). Nesse momento, porém, a despeito da contrariedade da família metodista, para a qual a vida correta e estável parece bastante, Wilson não se contenta com os limites de sua situação atual ou com as perspectivas que ela oferece. Sentindo-se habilitado pelos saberes encontrados na igreja que escolheu para si, esse indivíduo prefere não se sujeitar à ausência de fato da igualdade de oportunidades prescrita no direito. Ele acredita em si mesmo e em sua capacidade de se mover socialmente para muito além da sobrevivência e se responsabiliza pela demissão de seu modesto emprego de auxiliar de portaria. Ambicionando as compensações do "sucesso", meu informante, que em absoluto não é um caso isolado, parte para o investimento na carreira de empresário. "Porque a reunião ali, acaba sendo uma... [...] palestra também, né?... [...] Ele tenta te ensinar a batalhar por uma vida melhor, mas com Deus, né?...".

Já explorei (Lima, no prelo) o argumento de que o crescimento do número de adeptos da IURD, na década de 1990, está relacionado ao fato de que os símbolos articulados em sua mensagem pastoral voltada para a salvação neste mundo são condizentes com os princípios econô- 
“Prosperidade" na Década de 1990: Etnografia do Compromisso de Trabalho...

micos, muito bem sintetizados pela categoria empreendedorismo, que passaram a fornecer sentido à grande parcela das relações sociais - sobretudo as relações que regem o mundo do trabalho - no Brasil a partir daquele momento. A continuidade da etnografia indica, porém, que há ainda o que elucidar. O senso comum sabe que a IURD é a igreja dos "ex-tudo", de modo que o passado conturbado de meus sujeitos de pesquisa não é o que me surpreende. Quero saber por que, para Wilson, o respeito e a preferência que sua mãe ("do Norte, coitada, pensionista...") nutre pelo emprego na Petrobras ou no Banco do Brasil é motivo de riso. O que aconteceu com a expectativa de que o Estado inseriria os indivíduos no sistema produtivo? Por que Jefferson - um terceiro integrante da rede de informantes que venho tecendo no lento processo etnográfico que persigo -, pouco depois de, com o "espírito rendido a Deus", deixar as drogas e os pequenos furtos que sustentavam seu vício, e, "por Deus", passar a "trabalhar certinho", não apenas passou a "trabalhar certinho", mas resolveu que "nunca mais trabalhar [ia] pra ninguém"?

Vinícius, Wilson e Jefferson não ocupam posição estratégica em nenhuma organização produtiva ou financeira, isso é óbvio. O que ainda me parece merecer insistência analítica, entretanto, é o fato de que eles não são meramente pobres e desempregados. Além de pobres e muito precariamente escolarizados, não têm qualquer qualificação e, portanto, não estão em nenhuma categoria ocupacional, nunca tiveram experiência associativa nem foram beneficiados por nenhum mecanismo social de inserção; nem eles, nem seus pais ou irmãos. Eles têm, em teoria, sua "força de trabalho" para vender e poderiam começar como "serventes" na indústria. Como descreve um dos operários analisados por Lopes (1978:53), o "serviço de servente é um serviço pesado. Não tem profissão nenhuma, não aprenderam nada, coitados [...]". Mas eles vivem em um contexto metropolitano de progressiva dificuldade de emprego e de baixos salários, e são, pelo menos, a segunda geração ${ }^{19} \mathrm{de}$ homens ${ }^{20}$ que enfrentam uma situação de marginalidade ao sistema produtivo. Em suas histórias de vida, o trabalho ou a inserção em um contexto de labor não era uma referência para a constituição de sua identidade, como era a pesca para os pescadores da Jurujuba antropologicamente investigada por Duarte (1999), ou a indústria automobilística para os operários que marcaram a história recente deste país. Vinícius e seus irmãos, como já vimos, eram o que se classifica como "adolescente em conflito com a lei", antes de serem evangelizados. Ele 
se mantinha na escola como estratégia para se proteger da polícia. Seu pai fazia transporte de carga por conta própria.

Antes de se converter ao neopentecostalismo, aos 18 ou 19 anos, Wilson, órfão de pai desde os 2 anos, teve seis empregos: foi terceiro servente em uma oficina de estofamento, "mas era muito esforço pro dinheiro que dá e aquilo [o] deixava perturbado"; entregou "quentinhas"; foi contínuo em três empresas - onde começou a "abrir a mente" - e foi porteiro de um edifício comercial. Depois que entrou para a Igreja Universal, teve "coragem de largar a portaria" e montou uma barraca de camelô, até se tornar corretor de seguros e "mudar de vida". "Eu não sei se tu já notou isso. Tu não deve saber porque tu é professora lá da universidade. Mas no Brasil, o camarada que faz o trabalho mais árduo é o que menos ganha, é o mais lascado. Eu acho isso injusto".

A carreira de Jefferson, cujo pai "só vivia aprontando", é semelhante: começou a trabalhar como contínuo aos 15 anos de idade. Ao mesmo tempo em que trabalhava, "roubava demais" porque "era muito viciado", ele e o irmão. "Vivia enrolado, entrando e saindo de emprego, porque levava roubo pra vender lá dentro". Quando seu irmão foi morto pela polícia, e depois que ele mesmo teve vários "problemas com a polícia" - e mesmo "um bandido quis [me] mat[ar]" -, Jefferson decidiu acompanhar sua mãe à Igreja Universal e "mudar de vida". "É engraçado que o pessoal fala que a nossa Igreja pede dinheiro e tal, e a gente não tinha nada pra dar. Era uma miséria que tu não tem idéia. Só comia passarinha de boi". Com o "espírito rendido a Deus", deixou as drogas e, "por Deus", passou a "trabalhar certinho. Mas não dava." "Não é que ele não tinha coragem pra trabalhar, quando a gente se acertou, só que é muita humilhação também que tu tem que ouvir", intervém sua esposa. "Era uma bomba. Porque eu era frentista, passavam cheque sem fundo e quem recebia era quem pagava o dono do posto", completa Jefferson.

Em grande parte, os fiéis da Igreja Universal do Reino de Deus já eram autônomos antes de aderirem a ela e à sua mensagem sobre o trabalho "por conta própria". Eram, porém, o que prefiro classificar como negativamente autônomos, no lugar de "abandonados" ou "esquecidos" pelas políticas sociais. Com efeito, eles nunca foram contemplados por mecanismos públicos de inclusão e são provenientes das franjas mais desfavorecidas da pobreza urbana, às quais só resta, para a sobrevivência, o mercado de pequenos serviços ou a criminalidade. Seu isola- 
“Prosperidade" na Década de 1990: Etnografia do Compromisso de Trabalho...

mento é tamanho que Wilson imagina que eu, por ser professora da universidade, não teria notado que o "trabalho mais árduo" é o mais mal remunerado. Jefferson viveu tão estremado de qualquer informação sobre a vida econômica formal que até pouco tempo não cumpria suas obrigações tributárias porque, simplesmente, não tinha notícia da existência de impostos.

No entanto, em suas narrativas sobre suas trajetórias, o Estado jamais é mencionado ${ }^{21}$, o que me leva a julgar impreciso e mesmo injusto, em uma análise sobre a maneira como estão e como representam sua posição na realidade, qualificá-los como uma massa que existe em relação a ou englobada por algo que para eles não existe nem mesmo para ser acusado de ter falhado ou faltado. Não estou, em absoluto, sugerindo que o Estado não deva levá-los em consideração, que não tenha falhado ou faltado. Todavia, minha ênfase está, aqui, voltada para a experiência subjetiva de sua condição social e para a maneira como falam de si mesmos, como fala de si mesmo aquele rapaz que, aos 13 anos, avaliou que estar na escola era uma boa estratégia para driblar a polícia, indicando que sempre tiveram autonomia, que nunca lhes foi dada alternativa a não ser a de se responsabilizarem pelo empreendimento de seu destino social e que, finalmente, essa é, mesmo, uma marca identitária que lhes é cara. Embora isolados e fragilizados por conta desse isolamento no mercado de trabalho, adjetivá-los de "abandonados", "esquecidos", "excluídos" ou, enfim, "vítimas", seria, mais do que um equívoco interpretativo sobre o modo desses homens de camadas populares estarem em um mundo ausente de instituições inclusivas, um desrespeito à representação que fazem de si mesmos e que os moveu à conversão a essa denominação pentecostal que os ensina a trabalhar "com Deus" por uma "vida melhor".

A mesma mídia que, nos anos 1990, através de matérias sobre "chiques e famosos"22, os alfabetizou na cartilha do mercado, ao divulgar a equação positiva "batalha" eficiente e competitiva é igual a "sucesso", discute em rede nacional, desde a década de 1970, questões fundantes do ideário individualista moderno, como é o caso das telenovelas que abordam a oposição "tradição" e "modernidade", "hierarquia" e "individualismo" (cf. Hamburger, 2005) através da exploração, por exemplo, de personagens que migram dos meios rurais para os centros urbanos em busca de oportunidade. Desse modo, se é verdade que suas visões de si mesmos como "indivíduos modernos" que avaliam racionalmente uma teologia, fazem uma escolha e, em seguida, "batalham" 
pela "prosperidade" ecoam o discurso iurdiano, que, por sua vez, está em consonância com a linguagem contemporânea do dever ser da economia, presente no jornalismo impresso e televisivo, penso ser importante registrar que em algum nível um processo de individualização já estava em curso antes da adesão ${ }^{23}$. Nas palavras de Wilson: "Esse meu pensamento [sobre trabalhar por conta própria], eu sempre tive, só que eu era medroso. Demais. Levou uns dois três anos pr'eu amadurecer, depois que eu entrei na fé. Mas eu não era como o meu irmão, eu sempre tive o espírito incomodado".

A cosmologia da Igreja Universal concebe seus fiéis como dizimistas que têm o dever de contribuir para a "Obra de Deus", para que o "Mal" seja eliminado e a "abundância" possa chegar a todos. A idéia de que, como contrapartida do dízimo, os fiéis têm o direito de se sentirem sócios de Deus em seus empreendimentos de felicidade terrena é reiterada pelo clero da IURD, toda segunda-feira. A escuta etnográfica evidencia que, para os fiéis, esse dízimo é trocado por coragem. Sujeitos sociais como Vinícius, Wilson e Jefferson já eram autônomos no empreendimento de seus destinos sociais quando aderiram à Igreja Universal. Eles também já eram "batalhadores". O estímulo da IURD ao trabalho empreendedor e sua promessa de que Deus se compromete com essa aventura os ajudou a ousar para converterem a negatividade de sua condição instável em "perseverança" e "vitória". O encontro espiritual atenuou o sentimento de fragilidade provocado por seu isolamento e os impeliu a "lutar com Deus, por uma vida melhor". "E tá dando certo, né?", conclui, Jefferson, ao me mostrar as fotografias que guarda do fim de semana passado no Méditerranée com sua mulher, a título de prêmio de vendas que ganhou de uma das empresas de previdência privada que representa.

\section{CONCLUSÃO}

Meu investimento analítico nessa denominação pentecostal específica se deve à discrepância entre as acusações - proferidas pelo senso comum bem como por uma parcela importante da bibliografia desenvolvida no campo da religião, no Brasil - sobre a maneira como manipularia a ingenuidade dos fiéis através do uso da linguagem mercantil e o expressivo crescimento do número de membros na década de 1990. É sabido que os sujeitos sociais buscam na religião soluções para suas aflições. Restava responder por que, desde a década de 1990, parte das camadas mais pobres da sociedade brasileira vem recorrendo à Teolo- 
“Prosperidade" na Década de 1990: Etnografia do Compromisso de Trabalho...

gia da Prosperidade em especial e a despeito de todas as objeções. O argumento de que a IURD atrai os pobres urbanos brasileiros, largamente expostos ao desemprego ou ao subemprego, porque lhes promete ascensão social não dá conta de esclarecer por que essa denominação pentecostal que professa a Teologia da Prosperidade desde a sua fundação em 1977 se torna atraente a ponto de ampliar seu número de fiéis em $25 \%$ a cada ano da década de 1990 .

Com efeito, o dinheiro está muito presente nas práticas da IURD, assim como em outras práticas religiosas ${ }^{24}$. Mas é só na Igreja Universal do Reino de Deus que, semanalmente, os fiéis se reúnem para o culto à prosperidade, no qual ouvem sobre a legitimidade da abundância no mundo e assistem a uma pregação muito semelhante ao que entendem como uma "palestra" sobre as coisas do mercado. O trabalho de campo desafia a representação de que os fiéis são ingênuos e manipulados pela sede de lucro dessa instituição religiosa "desonesta". Eles fazem seus cálculos seguindo uma lógica própria que em si mereceria um outro artigo. O certo é que os depoimentos sobre o pertencimento religioso, que obtive em um templo da Zona Sul do Rio de Janeiro, enfatizam noções como "escolha" e "decisão", caras ao horizonte individualista moderno da igualdade e da liberdade, e com muita recorrência ancoram sua explicação para as "mudanças" ocorridas em sua vida resultante da "entrada na fé" à "atitude" profissional empreendedora que puderam assumir a partir do que ouviram na Igreja Universal. Mais ainda, ao aprofundar a investigação sobre sua carreira ocupacional, fica claro que não era de autonomia nem de empreendedorismo que eles careciam antes da adesão, mas de coragem para, sozinhos, alinharem-se aos mandamentos do "mercado livre" e converterem em autonomia positiva a precariedade de suas circunstâncias sociais originais.

(Recebido para publicação em setembro de 2006) (Versão definitiva em setembro de 2007) 


\section{Diana Nogueira de Oliveira Lima}

\section{NOTAS}

1. Não se pode deixar de lado a evidência empírica de que, entre 1977 e 1990, o aumento do número de membros da IURD (com sua Teologia da Prosperidade) é muito tímido.

2. Embora não disponha de autonomia em relação à autoridade central da instituição, $\mathrm{o}$ ambiente religioso que venho observando desde outubro de 2005 guarda homologias fundamentais tanto com a noção weberiana de congregação quanto com os aspectos que caracterizam o pertencimento contemporâneo às associações modernas, recentemente analisados por Duarte (2006). Durante o trabalho de campo, verifico a intensidade da convivência cotidiana de redes sociais dentro da igreja e fora dali, em eventos sociais e, em alguns casos, no trabalho; o mútuo controle das qualidades espirituais entre fiéis e as redes de oração e ajuda que se formam para amparar aqueles que "dão mole" na fé e aqueles que estão passando por dificuldades de modo geral; a alusão e a freqüência à "igreja do Largo do Machado" para a identificação e significação de seu pertencimento religioso adquirido (muito mais recorrente que a representação de comunhão universal e que as visitas à Catedral).

3. Alguns fiéis, mas não todos, vêm dos morros próximos ao Largo do Machado, tais como o morro Santo Amaro, o morro Azul e o morro do Cosme Velho (Cerro Corá).

4. Quatro indicadores demográficos foram empregados para perfilar os grupos religiosos: situação de domicílio (urbano e rural), sexo, repartição etária, raça/cor. Os aspectos sociais foram definidos segundo a natureza da última união e o nível de educação. Para a avaliação dos aspectos econômicos, foram levados em conta o setor de atividade, a posição na ocupação, a natureza do trabalho e o rendimento total.

5. Os dados disponíveis no estudo Novo Nascimento. Os Evangélicos em Casa, na Igreja e na Política, relativos à região metropolitana do Rio de Janeiro e publicados em 1998, indicam que 63\% dos adeptos da IURD ganham até dois salários mínimos, 50\% têm até quatro anos de escolaridade.

6. Note-se que, enquanto a IURD cresceu $25 \%$ a cada ano na década de 1990 , durante esse mesmo período a população brasileira total aumentou apenas $2 \%$ anualmente.

7. Para um aprofundamento do tema da "Confissão Positiva" ou do poder performativo da linguagem, ver Mafra (2002) e também Fonseca (2000).

8. Os estudos sobre pentecostalismo já fizeram essa indagação. Ainda que não seja esse o ponto aqui em tela, creio que cabe esclarecer que a doutrina da Igreja Universal incorpora a acusação e a inscreve na lógica da perseguição. Dentro dessa lógica, a capacidade de sobrevivência e ampliação da IURD constitui prova de sua ligação privilegiada com Deus. Esse raciocínio, a mim, parece simbolicamente eficaz quando se trata do diálogo com os membros da Igreja Universal. Não creio, entretanto, ser suficiente como apelo para o recrutamento de novos fiéis.

9. Também chamada de "Reunião da Prosperidade".

10. Na Sede Mundial, mais de uma vez ouvi o bispo falar em quantias monetárias na casa do milhão.

11. Como é de costume, o nome dos informantes foi trocado de modo a preservar sua identidade. 
“Prosperidade" na Década de 1990: Etnografia do Compromisso de Trabalho...

12. Segundo explicação que me foi dada no campo, o preposto é alguém que se serve da licença fornecida pela Superintendência de Seguros Privados - Susep a uma outra pessoa para comercializar seguros. Nesse caso, ser preposto de alguém significa utilizar sua licença para trabalhar em troca de uma participação nos resultados das vendas efetuadas.

13. Durante a conversa, diversas vezes tentei descobrir o sentido que Vinícius, evasivo, dá a expressão "dei mole". Recentemente, soube por outro informante que "Vinícius matou um cara. Foi um assaltinho bobo, nada demais. O cara sai de pastor, não arruma emprego, tá com fome, vai fazer um assalto. Mas aí acontece aquilo: surge uma situação, aí o cara não tem saída. Ou ele mata o cara lá na hora ou os caras no morro vão dizer que ele amarelou e tal e matam ele".

14. Como diz Mintz: “A igreja, naquilo que ela proíbe e naquilo que estimula, fornece uma visão de mundo notoriamente compatível com as aspirações de mobilidade social em uma sociedade que está se ocidentalizando. As injunções contra o jogo, o cigarro e a bebida podem fazer muita diferença em termos de poupança ou pelo menos para a potencial acumulação de capital para outros propósitos" (1964:266, tradução da autora).

15. Ainda que os dados demográficos levantados em Fernandes (1998) apontem uma expressiva maioria de mulheres ( $81 \%$ de mulheres para $19 \%$ de homens) na comunidade de adeptos da Igreja Universal do Reino de Deus, tenho observado que, no templo do Largo do Machado, ambos os gêneros têm presença equivalente.

16. “Don Gosset, no livro Há Poder em suas Palavras, afirma: 'Louvado seja Deus, é verdade que, se você crê no que está dizendo, você recebe o que diz. Se você diz: Não posso pagar minhas contas, por exemplo, você não será capaz de pagar suas contas ainda que a Palavra de Deus diga que o meu Deus, segundo a sua riqueza em glória, há de suprir em Cristo Jesus cada uma de vossas necessidades (Filipenses 4:19). Mas, se você mudar sua maneira negativa de falar (ou pensar), com base na promessa de Deus de dar suprimento, você receberá o milagre financeiro de que está precisando" (apud Fonseca, 2000:68).

17. O uso da mídia eletrônica, a localização geográfica dos seus templos, os megaeventos de cura realizados no espaço público urbano são algumas das medidas proselitistas costumeiramente citadas na literatura.

18. Nenhum dos meus informantes tem informação sobre seus avôs.

19. A situação ocupacional das mulheres não será contemplada por esta análise que propõe penetrar a dimensão subjetiva da realidade retratada pelos dados estatísticos tão simplesmente porque, por enquanto, a rede de informantes a que consegui ter acesso é formada por homens.

20. Para ser mais precisa, o Estado apareceu duas vezes na conversa com Wilson que registrei. Sua mãe é "coitada, uma pensionista do INSS" (ênfase da autora). A expectativa que essa mãe nutria de que o filho trocasse o emprego na portaria pela segurança do serviço público é, para ele, motivo de riso. No mais, o Estado comparece na vida dessas pessoas para fazer papel policial.

21. Chiques e Famosos é uma das revistas que integram o segmento de mídia impressa empenhado em divulgar com entusiasmo o mundo dos "bem-sucedidos". 


\section{Diana Nogueira de Oliveira Lima}

22. O próprio movimento de adesão a uma religião, em vez da permanência na religião de nascimento, é sintoma da determinação dos valores modernos (nesse caso, o da liberdade de escolha individual) sobre os comportamentos (Duarte, 2005).

23. Não custa lembrar que as doações, ofertas, pagamentos e dízimos são uma realidade no encaminhamento de diversas religiões. É assim com as promessas no catolicismo, com os despachos e os pagamentos às mães e aos pais-de-santo nas religiões afro-brasileiras, e é assim também com o donativo judaico e com o dízimo em outras denominações protestantes.

\section{REFERÊNCIAS BIBLIOGRÁFICAS}

ABREU, Alzira Alves de. (2003), "Jornalistas e Jornalismo Econômico na Transição Democrática", in A. A. Abreu, F. Lattman-Weltman e M. A. Kornis, Mídia e Política no Brasil. Jornalismo e Fiç̧ão. Rio de Janeiro, Editora FGV.

BIRMAN, Patrícia e LEITE, Márcia P. (2000), “Whatever Happened to What Used to Be the Largest Catholic Country in the World?". Daedalus, vol. 129, № 2.

BITTENCOURT, José. (1994), "Remédio Amargo", in A. Antoniazzi et alii (eds.), Nem Anjos nem Demônios: Interpretações Sociológicas do Pentecostalismo. Petrópolis, Vozes.

BOLTANSKI, Luc e CHIAPELLO, Ève. (1999), Le Nouvel Esprit du Capitalism. Paris, Gallimard.

CAMPOS, Leonildo Silveira. (1997), Teatro, Templo e Mercado: Organização e Marketing de um Empreendimento Pentecostal. Petrópolis, Vozes.

CARNEIRO CAMPOS, Roberta. (1994), Perfil Sócio-Econômico dos Seduzidos à Igreja Universal do Reino de Deus. Trabalho apresentado no congresso internacional As Novas Religiões - A Expansão dos Movimentos Religiosos e Mágicos. Recife, Universidade Federal de Pernambuco, 18 de maio.

DUARTE, Luiz Fernando Dias. (1999), As Redes do Suor. A Reprodução Social dos Trabalhadores da Pesca em Jurujuba. Niterói, EdUFF.

. (2005), "Ethos Privado e Justificação Religiosa. Negociações da Reprodução na Sociedade Brasileira", in M. L. Heilborn et alii (orgs.), Sexualidade, Família e Ethos Religioso. Rio de Janeiro, Garamond, pp. 137-176.

. (2006), “Ethos Privado e Modernidade: O Desafio das Religiões entre Indivíduo, Família e Congregação", in L. F. D. Duarte et alii (orgs.), Família e Religião. Rio de Janeiro, Contra Capa, pp. 51-87.

FERNANDES, Florestan. (1978), A Integração do Negro na Sociedade de Classes. São Paulo, Ática.

FERNANDES, Rubem César. (1998), Novo Nascimento: Os Evangélicos em Casa, na Igreja e na Política. Rio de Janeiro, Mauad. 
“Prosperidade" na Década de 1990: Etnografia do Compromisso de Trabalho...

FONSECA, Alexandre Brasil. (2000), “Nova Era Evangélica, Confissão Positiva e o Crescimento dos Sem-Religião". NUMEN, Revista de Estudos e Pesquisa da Religião, vol. 3, no 2, pp. 63-90.

FRANCO, Maria Sylvia de Carvalho. (1997), Homens Livres na Ordem Escravocrata. São Paulo, Editora Unesp.

FRESTON, Paul. (1993), Protestantes e Política no Brasil: Da Constituinte ao Impeachment. Tese de doutorado, Unicamp, Campinas.

FREYRE, Gilberto. (2003) [1951], Decadência do Patriarcado Rural e Desenvolvimento do Urbano. São Paulo, Global.

GEERTZ, Clifford. (1989), A Interpretação das Culturas. Rio de Janeiro, LTC Editora.

GIUMBELLI, Emerson. (2001), “A Vontade de Saber: Terminologias e Classificações sobre o Protestantismo Brasileiro". Religião e Sociedade, vol. 21, no 1, pp. 87-120.

GOMES, Edlaine de Campos. (2004), A “Era das Catedrais" da IURD: A Autenticidade em Exibição. Tese de doutorado, Programa de Pós-Graduação em Ciências Sociais, UERJ, Rio de Janeiro.

HAMBURGER, Esther. (2005), Brasil Antenado. A Sociedade da Novela. Rio de Janeiro, Jorge Zahar.

HORTAL, Jesús. (1991), "Panorama e Estatísticas do Fenômeno Religioso no Brasil”, in CNBB (org.), A Igreja Católica diante do Pluralismo Religioso no Brasil (I). São Paulo, Paulinas.

(1994), “As Novas Tendências Religiosas: Uma Reflexão sobre as Causas e Conseqüências", in CNBB (org.), A Igreja Católica diante do Pluralismo Religioso no Brasil (III). São Paulo, Paulinas.

LIMA, Diana N. O. (no prelo), Sujeitos e Objetos do Sucesso. Uma Antropologia do Brasil Emergente. Rio de Janeiro, Garamond.

LOPES, José Sérgio Leite. (1978), O Vapor do Diabo. O Trabalho dos Operários do Açúcar. Rio de Janeiro, Paz e Terra.

MACEDO, Edir. (2005), Nos Passos de Jesus. Rio de Janeiro, Editora Gráfica Universal Ltda.

MAFRA, Clara. (2002), Na Posse da Palavra. Religião, Conversão e Liberdade Pessoal em Dois Contextos Nacionais. Lisboa, Imprensa de Ciências Sociais/Instituto de Ciências Sociais da Universidade de Lisboa.

MARIANO, Ricardo. (1996), “Os Neopentecostais e a Teologia da Prosperidade”. Novos Estudos Cebrap, no 44, pp. 24-44.

MARIZ, Cecília L. (1995), “Perspectivas Sociológicas sobre o Pentecostalismo e o Neopentecostalismo". Revista de Cultura Teológica, no 3, pp. 37-52.

e MACHADO, Maria das Dores C. (1998), “Mudanças Recentes no Campo Religioso Brasileiro". Antropolítica, vol. 5, pp. 21-43.

MESQUITA, Wania. (2003), Em Busca da Prosperidade: Trabalho e Empreendedorismo entre Neopentecostais. Tese de doutorado em Sociologia, Iuperj, Rio de Janeiro. 


\section{Diana Nogueira de Oliveira Lima}

MINTZ, Sidney. (1964), Worker in the Cane. A Puerto Rican Life History. New Haven/London, Yale University Press.

NOVAES, Regina. (1985), Os Escolhidos de Deus. Pentecostais, Trabalhadores e Cidadania. Rio de Janeiro, Marco Zero.

ORO, Ari Pedro. (1993), “Podem Passar a Sacolinha': Um Estudo sobre as Representações do Dinheiro no Pentecostalismo Autônomo Brasileiro Atual". Revista Eclesiástica Brasileira, vol. 1, no 210, pp. 301-323.

et alii. (2003), Igreja Universal do Reino de Deus: Os Novos Conquistadores da Fé. São Paulo, Paulinas.

SAHLINS, Marshall. (1996), "The Sadness of Sweetness: The Native Anthropology of Western Cosmology". Current Anthropology, vol. 37, no 3, pp. 395-428.

SIEPIERSKI, Paulo. (1997), “Pós-Pentecostalismo e Política no Brasil”. Estudos Teológicos, vol. 1, no 37, pp. 47-70.

SOUZA, Jessé. (2003), A Construção Social da Subcidadania. Para uma Sociologia Política da Modernidade Periférica. Belo Horizonte/Rio de Janeiro, Editora UFMG/Iuperj.

VELHO, Gilberto. (1987), Individualismo e Cultura. Rio de Janeiro, Jorge Zahar.

WEBER, Max. (1982), "As Seitas Protestantes e o Espírito do Capitalismo", in Ensaios de Sociologia. Rio de Janeiro, Guanabara Koogan.

WERNECK VIANNA, Luiz. (2006), Esquerda Brasileira e Tradição Republicana. Estudos de Conjuntura sobre a Era FHC-Lula. Rio de Janeiro, Revan. 
“Prosperidade" na Década de 1990: Etnografia do Compromisso de Trabalho...

\author{
ABSTRACT \\ "Prosperity" in the 1990s: Ethnography of the Work Commitment \\ Between Worshippers and God in the Universal Church of the Kingdom of \\ God
}

In the 1990s, when Brazil was experiencing "trade opening", terms that were already dear to "neo-liberal" ideals such as "competitiveness", "entrepreneurship", and "success" slowly seeped into Brazilian society's imagination. Meanwhile, there was a sharp rise in membership in the Universal Church of the Kingdom of God, which defends the "Theology of Prosperity". In this article I examine information gathered through an ethnographic survey of worshippers at a UCKG congregation in Rio de Janeiro in order to expand the understanding of the aspirations, dispositions, and experiences of these lower-income social actors who chose to embrace this religious faith in the 1990s.

Key words: autonomy; market; God; work

\title{
RESUMÉ \\ "Prospérité" dans les Années 1990: Ethnographie de l'Engagement de Travail entre Dieu et les Fidèles de l'Église Universelle du Royaume de Dieu
}

Dans les années 1990, lorsque le Brésil vit "son ouverture commerciale", des termes chers à l'idéologie néolibérale tels que "compétitivité", "esprit d'entreprise", "succès" etc. viennent s'installer progressivement dans l'imaginaire de la société brésilienne. Àla même époque, il y a une forte montée du nombre d'adeptes de l'Église Universelle du Royaume de Dieu, qui prône la "Théologie de la Prospérité". Dans cet article, on examine des informations réunies en ethnographie parmi des fidèles d'un temple de l'IURD dans la ville de Rio de Janeiro, afin de mieux comprendre de qui il s'agit et quels sont les souhaits, envies et vécus de ces sujets issus de couches populaires qui, à ce moment donné, choisissent une telle doctrine religieuse.

Mots-clé: autonomie; marché; Dieu; travail 